\title{
2. SYNOPSIS
}

\begin{tabular}{|c|c|c|}
\hline $\begin{array}{l}\text { lpany: } \\
\text { léiades } \\
\text { evoie - FRANCE }\end{array}$ & $\begin{array}{l}\text { Individual Study Table } \\
\text { Referring to Part } \\
\text { of the Dossier }\end{array}$ & $\begin{array}{l}\text { For } 1 \\
\text { only) }\end{array}$ \\
\hline & Volume: & \\
\hline & \begin{tabular}{|l|l} 
Page: \\
\end{tabular} & \\
\hline \multicolumn{3}{|c|}{$\begin{array}{l}\text { Title of study: Early treatment of Idiopathic Parkinson's Disease (IPD) with dopaminergic agonist piribedil } \\
\text { in monotherapy (adaptation of the daily dose from } 150 \text { to } 300 \mathrm{mg} \text { per day per os). A 2-year randomised, } \\
\text { parallel group, placebo controlled study in IPD "de novo" patients. } \\
\text { A planned short-term assessment of the initial } 7 \text { months of treatment. } \\
\text { Protocol No.: CL3-04200-006 }\end{array}$} \\
\hline \multicolumn{3}{|l|}{ Iain coordinator: } \\
\hline \multicolumn{3}{|c|}{$\begin{array}{l}\text { Study centres: } \\
52 \text { active centres in } 7 \text { countries (10 in Argentina, } 6 \text { in India, } 6 \text { in France, } 5 \text { in Mexico, } 7 \text { in South Africa, } 14 \text { in } \\
\text { Spain and } 4 \text { in Portugal). }\end{array}$} \\
\hline \multirow{2}{*}{\multicolumn{3}{|c|}{$\begin{array}{l}\text { Publications (reference): } \\
\text { Lees A et al. Piribedil efficacy in monotherapy (150-300 mg/day) in de novo parkinsonian patients: a 6-month } \\
\text { planned intermediate analysis of the 2-year Parkinson-REGAIN study. Neurology 2004;62 (Suppl. 5):A399. } \\
\text { Rascol O et al. Piribedil efficacy in monotherapy (150-300 mg/day) in de novo parkinsonian patients: a } \\
\text { 6-month planned intermediate analysis of the 2-year parkinson REGAIN study. Movement Disorders } \\
\text { 2004;19(Suppl. 9):603. }\end{array}$}} \\
\hline & & \\
\hline \multicolumn{2}{|c|}{$\begin{array}{l}\text { Studied period: } \\
\text { Initiation date: } 10 \text { May } 2001 \text { (first selection visit) } \\
\text { Cut off date: } \quad 15 \text { May } 2003 \text { (last visit in short-term assessment) }\end{array}$} & \\
\hline \multicolumn{3}{|c|}{$\begin{array}{l}\text { Objectives: } \\
\text { To compare the therapeutic effect of piribedil to placebo in L-dopa naïve out-patients with motor symptoms } \\
\text { of early stage (Hoehn and Yahr Stage } 1 \text { to 3) IPD: }\end{array}$} \\
\hline \multirow{2}{*}{\multicolumn{3}{|c|}{$\begin{array}{l}\text { - Short-term evaluation ( } 7 \text { months): To demonstrate the superiority of piribedil to placebo as measured by } \\
\text { change from baseline to last post-baseline visit in UPDRS III total score in monotherapy; } \\
\text { - Long-term evaluation ( } 24 \text { months): To demonstrate the superiority of piribedil to placebo as measured by } \\
\text { (1) the time to develop and (2) the number of patients developing "dyskinesia" or other motor } \\
\text { complications, irrespective of the addition of L-dopa. }\end{array}$}} \\
\hline & & \\
\hline \multicolumn{3}{|l|}{ This report presents the results of } \\
\hline \multicolumn{3}{|c|}{$\begin{array}{l}\text { 1, double-blind, placebo-controlled, parallel-group study to assess the } \\
\text { on de novo patients with IPD. Randomisation was stratified by centre. }\end{array}$} \\
\hline \multicolumn{3}{|c|}{$\begin{array}{l}\text { Number of patients: } \\
\text { Planned: } 400 \text { (200 per group); Treated: } 405 \text { (205 placebo / } 200 \text { piribedil) } \\
405 \text { included patients: Argentina-72; India-96; France-14; Mexico-59; South Africa-47; Spain-91; } \\
\text { Portugal-26. }\end{array}$} \\
\hline \multicolumn{3}{|c|}{$\begin{array}{l}\text { on: } \\
\text { and } 77 \text { years, who were out-patients with diagnosed IPD (defined by } \\
\text { yy other known or suspected cause of parkinsonism, Hoehn and Yahr } \\
\text { aïve to L-dopa ( }<6 \text { weeks previous treatment) and no more than }\end{array}$} \\
\hline
\end{tabular}




\begin{tabular}{|l|l|l|}
\hline $\begin{array}{l}\text { Name of Company: } \\
\text { I.R.I.S. }\end{array}$ & $\begin{array}{l}\text { Individual Study Table } \\
\text { Referring to Part } \\
\text { of the Dossier }\end{array}$ & $\begin{array}{l}\text { (For National Authority Use } \\
\text { only) }\end{array}$ \\
\hline $\begin{array}{l}\text { Name of } \\
\text { Trivastales } \text { Finished } 50 \text { mg LP }\end{array}$ & Volume: & \\
\hline $\begin{array}{l}\text { Name of Active Ingredient: } \\
\text { Piribedil (S4200) }\end{array}$ & Page: & \\
\hline
\end{tabular}

Safety variables:

- All adverse events (AEs), emergent adverse events (EAEs) and serious adverse events (SAEs) occurring up to Month 7.

- Change from baseline to last visit in haematology and biochemistry parameters.

- Changes from baseline in vital signs (weight, blood pressure and heart rate).

Statistical methods:

- The Randomised Set (RS) consisted of all included and randomised patients (by IVRS).

- The Full Analysis Set (FAS) consisted of patients from the RS who received at least 1 dose of trial medication, who have a baseline and at least 1 post-baseline value for UPDRS III.

- The Per Protocol Set (PPS) consisted of patients in the FAS who followed the study until Month 7 and had no protocol deviation that might interfere with the main efficacy criteria.

- The Safety Set (SS) consisted of all included patients who received at least 1 dose of trial medication.

- The Cognitive Wis Per Protocol Set (CPPSM7-W) consisted of patients in the FAS, with no missing values and who had good protocol compliance for at least 1 baseline test and 1 post-baseline Wisconsin test, with no protocol deviations and MADRS score $<30$ at D0 and had Wisconsin test data at Month 7 .

- The Cognitive SVDR Per Protocol Set (CPPSM7-SVDR) consisted of patients in the FAS, with no missing values and who had good protocol compliance for at least 3 baseline tests and 3 post-baseline tests, with no protocol deviations and MADRS score $<30$ at D0 and had Stroop, verbal fluency, digit ordering and "reverse form" of digit symbol test data at Month 7.

For the purposes of the short-term assessment, last post-baseline visit was defined as the last non-missing value recorded after inclusion (up to Month 7). The last non-missing value in monotherapy was defined as the last non-missing value recorded after inclusion and before any introduction of L-dopa therapy (up to Month 7). A missing value at baseline was to be replaced by the value at the selection visit.

The main analysis of the primary efficacy variable (change in UPDRS III total score between baseline and last post-baseline visit in monotherapy) was performed using an ANCOVA (fixed effects: previous L-dopa, country; covariate: baseline UPDRS III total score) and a $2.5 \%$ level of significance (1-sided) to show superiority of piribedil in the FAS. Sensitivity analyses were also performed, taking into account centre as a random effect, and missing values on the RS (using Gould's method). As there is only 1 primary analysis, no adjustments for multiplicity were needed. Treatment response in monotherapy was analysed using logistic regression (independent variables: baseline, country and treatment).

All secondary efficacy variables were analysed descriptively at each visit and at each visit in monotherapy. Changes in UPDRS subscores from baseline to last visit in monotherapy were analysed using an ANCOVA (fixed effects: previous L-dopa, country; covariate: baseline UPDRS III subscore). Changes in UPDRS II (ADL) score from baseline to last visit in monotherapy were analysed using an ANCOVA (fixed effects: previous L-dopa, country; covariate: baseline UPDRS II [ADL score]). Time to therapeutic failure was analysed using Kaplan-Meier's method and Cox proportional hazards model (Likelihood ratio test; covariates: baseline Hoehn and Yahr stage, previous L-dopa, country). L-dopa dose was analysed as change from first to last prescribed dose. The final L-dopa dose was analysed using an ANOVA (fixed effects: previous L-dopa, Hoehn and Yahr stage). UPDRS V (Hoehn and Yahr) was analysed using an ANCOVA (fixed effect: country; covariate: baseline Hoehn and Yahr stage). Analyses of secondary efficacy variables were performed at a 5\% level of significance (2-sided comparisons) using both the FAS and the PPS, except in the dyskinesia and clinical fluctuations scale, UPDRS V, UPDRS VI and the dyskinesia rating scale, all of which were performed on the FAS only. Descriptive statistics were presented for cognitive function (Stroop, verbal fluency, digit ordering and reverse form of digit symbols tests) and analysed by ANCOVA (adjusting for country [fixed effect] and baseline). A correlation analysis was also performed, using change from baseline to last post-baseline visit and age at selection, years of education, disease duration at selection, motor examination score, Hoehn and Yahr score and MADRS total score. In addition to the FAS, the analysis of the criteria for the Stroop test, verbal fluency, digit ordering and reverse form of digit symbol test was performed on the CPPSM7-SVDR. The analysis of the Wisconsin Card Sorting test was performed on the CPPSM7-W. 


\begin{tabular}{|c|c|c|c|}
\hline $\begin{array}{l}\text { Name of Company: } \\
\text { I.R.I.S. } \\
6 \text { place des Pléiades } \\
\text { 92415 Courbevoie - FRANCE }\end{array}$ & $\begin{array}{l}\text { Individual Study } \\
\text { Referring to Par } \\
\text { of the Dossier }\end{array}$ & & $\begin{array}{l}\text { (For National Authority } U \\
\text { only) }\end{array}$ \\
\hline $\begin{array}{l}\text { Name of Finished Product: } \\
\text { Trivastal® } 50 \mathrm{mg} \text { LP }\end{array}$ & \multicolumn{2}{|l|}{ Volume: } & \\
\hline $\begin{array}{l}\text { Name of Active Ingredient: } \\
\text { Piribedil (S4200) }\end{array}$ & \multicolumn{2}{|l|}{ Page: } & \\
\hline \multicolumn{4}{|c|}{$\begin{array}{l}\text { Statistical methods (Cont'd): } \\
\text { All safety data were analysed by treatment group in the SS of patients and pooled for a description } \\
\text { SAEs and EAEs as well as by visit for descriptions of vital signs and biological parameters. }\end{array}$} \\
\hline \multicolumn{4}{|l|}{$\begin{array}{l}\text { Summary - Conclusions: } \\
\text { Study population and outcome: }\end{array}$} \\
\hline \multicolumn{2}{|r|}{ Placebo } & Piribedil & Whole population \\
\hline Included & 205 & 200 & 405 \\
\hline Randomised Set (RS) & 204 & 197 & 401 \\
\hline Lost to Follow-up before Month 7 (n [\%]) & $[\%])$ & $3(1.5)$ & $3(0.7)$ \\
\hline Withdrawn: & $25(12.3)$ & $40(20.3)$ & $65(16.2)$ \\
\hline due to adverse event (n [\%]) & $5(2.5)$ & $15(7.6)$ & $20(5.0)$ \\
\hline due to non-medical reason ( $\mathrm{n}[\%]$ ) & $13(6.4)$ & $13(6.6)$ & $26(6.5)$ \\
\hline due to protocol deviation (n $[\%]$ ) & $0(0.0)$ & $6(3.0)$ & $6(1.5)$ \\
\hline due to lack of efficacy (n [\%]) & $7(3.4)$ & $3(1.5)$ & $10(2.5)$ \\
\hline & $179(87.7)$ & $157(79.7)$ & $336(83.8)$ \\
\hline Full Analysis Set (FAS) (n [\%]) & $199(97.5)$ & $187(94.9)$ & $386(96.3)$ \\
\hline & $154(75.5)$ & $136(69.0)$ & $290(72.3)$ \\
\hline $\begin{array}{l}\text { Per Protocol Set (PPS) (n [\%]) } \\
\text { Safety Set (SS) (n [\%]) }\end{array}$ & $205(100.5)$ & $200(101.5)$ & $405(101.0)$ \\
\hline
\end{tabular}

Main baseline characteristics of the RS:

\begin{tabular}{|c|c|c|c|c|}
\hline & & $\begin{array}{l}\text { Placebo } \\
\mathrm{N}=204\end{array}$ & $\begin{array}{l}\text { Piribedil } \\
\mathbf{N}=197\end{array}$ & $\begin{array}{c}\text { Whole population } \\
\mathbf{N}=\mathbf{4 0 1}\end{array}$ \\
\hline \multirow[t]{2}{*}{ Age (years) } & Mean (SD) & $62.3(10.3)$ & $62.4(9.5)$ & $62.3(9.9)$ \\
\hline & Min - Max & $32-78$ & $30-77$ & $30-78$ \\
\hline Gender & Male n (\%) & $128(62.7 \%)$ & $116(58.9 \%)$ & $244(60.8 \%)$ \\
\hline Family history of PD & No $n(\%)$ & $182(89.2 \%)$ & $176(89.3 \%)$ & $358(89.3 \%)$ \\
\hline PD duration (years) & Mean (SD) & $1.97(2.04)$ & $1.99(1.80)$ & $1.98(1.92)$ \\
\hline Previous treatment for PD & No n $(\%)$ & $125(61.3 \%)$ & $105(53.3 \%)$ & $230(57.4 \%)$ \\
\hline Dopamine agonists & $\mathrm{N}(\%)$ & $11(5.4 \%)$ & $18(9.1 \%)$ & $29(7.2 \%)$ \\
\hline Dopa and derivatives & $\mathrm{N}(\%)$ & $19(9.3 \%)$ & $30(15.2 \%)$ & $49(12.2 \%)$ \\
\hline Adamantane derivatives & $\mathrm{N}(\%)$ & $12(5.9 \%)$ & $24(12.2 \%)$ & $36(9.0 \%)$ \\
\hline Tertiary amines & $\mathrm{N}(\%)$ & $38(18.6 \%)$ & $36(18.3 \%)$ & $74(18.5 \%)$ \\
\hline Hoehn and Yahr & Mean (SD) & $2(0.5)$ & $2.1(0.5)$ & $2(0.5)$ \\
\hline MADRS score & Mean (SD) & $6.5(7.2)$ & $7.7(7.2)$ & $7.1(7.2)$ \\
\hline UPDRS III score & Mean (SD) & $23.1(11.5)$ & $25.9(11.7)$ & $24.5(11.7)$ \\
\hline
\end{tabular}

The mean study treatment duration was $203.0 \pm 46.8$ and $190.1 \pm 60.3$ days in placebo and piribedil groups, respectively.

\section{Efficacy Results:}

Primary efficacy variable - UPDRS III total score (last post-baseline change in monotherapy):

\begin{tabular}{lcc}
\hline & Placebo & Piribedil \\
\hline FAS (n= 386) & 199 & 187 \\
Last change (mean [SD]) & $2.6[8.9]$ & $-4.9[9.8]$ \\
ANCOVA : LS mean difference $(95 \%$ CI) & $7.26(5.38,9.14) ; \mathrm{p}<0.0001$ \\
Sensitivity analysis (ANCOVA) LS mean difference $(95 \% \mathrm{CI})$ & $7.27(5.45,9.09) ; \mathrm{p}<0.0001$ \\
\hline PPS (n= 290) & 154 & 136 \\
Last change (mean [SD]) & $1.3[8.5]$ & $-5.6[9.9]$ \\
ANCOVA : LS mean difference $(95 \% \mathrm{CI})$ & $6.77(4.64,8.89) ; \mathrm{p}<0.0001$ \\
\hline
\end{tabular}




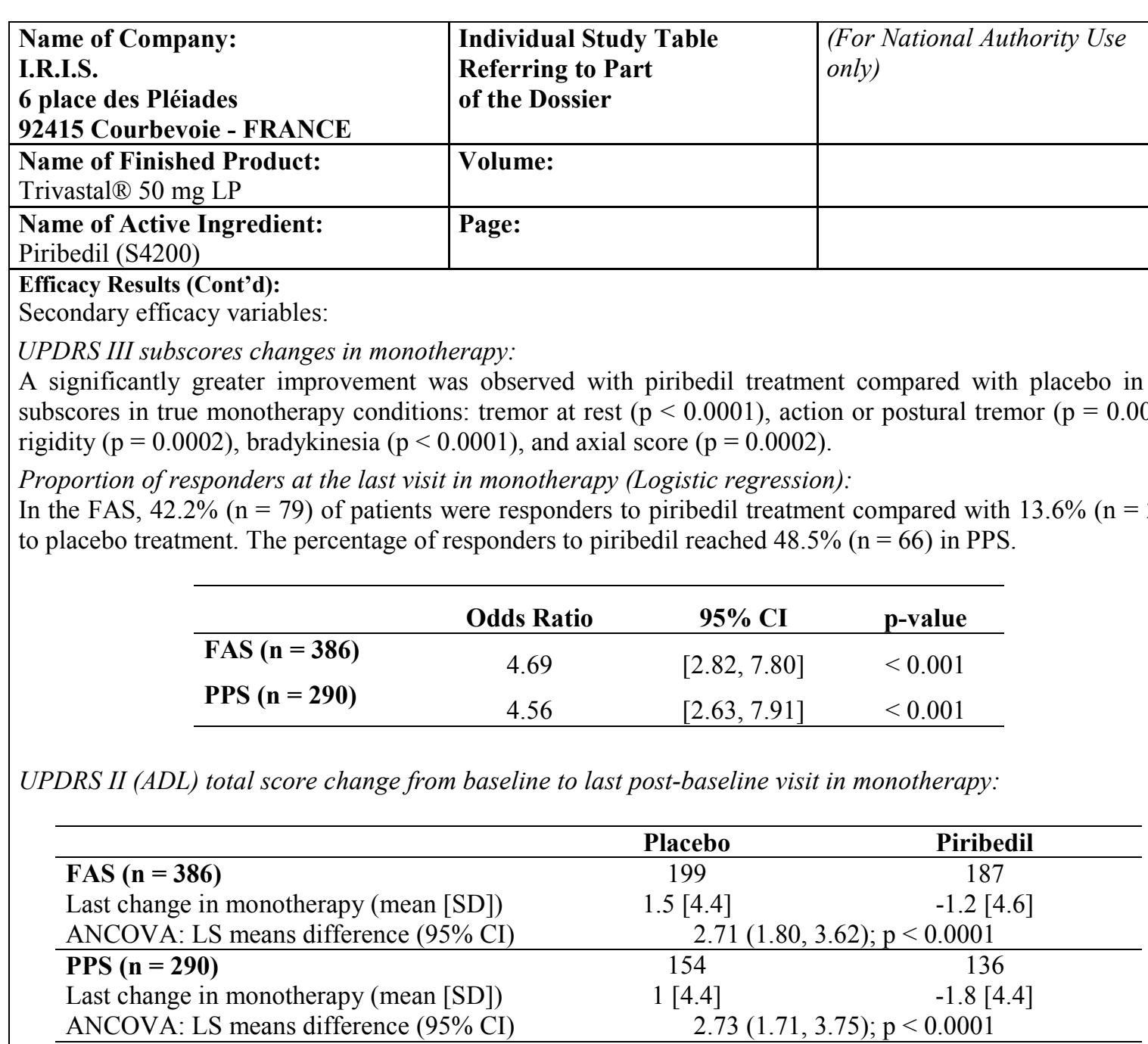

Time to introduction of L-dopa:

A lower proportion of piribedil-treated patients $(16.6 \%)$ than placebo-treated patients $(40.2 \%)$ received L-dopa rescue treatment during the 7 months of treatment. The proportion of patients taking L-dopa was significantly higher in the placebo group, with an Odds ratio of 3.72 for the FAS $(p<0.001)$. This result was supported by analysis of the PPS (Odds ratio of 3.2, $\mathrm{p}<0.001$ ) The relative risk of the need to introduce L-dopa rescue treatment during 7 months of treatment was 3.02 in the FAS and 2.72 in the PPS for placebo versus piribedil.

\begin{tabular}{lccc}
\hline Cox proportional Hazard Model & Relative risk* & $\mathbf{9 5 \%}$ CI & p-value \\
\hline FAS $(\mathbf{n}=\mathbf{3 8 6})$ & 3.02 & {$[1.96,4.65]$} & $<0.0001$ \\
PPS $(\mathbf{n}=\mathbf{2 9 0})$ & 2.72 & {$[1.62,4.58]$} & 0.0002 \\
\hline * Relative risk $=$ piribedil-placebo; Analysis adjusted for UPDRS III baseline and country
\end{tabular}

Placebo patients generally received a significantly higher last prescribed L-dopa daily dose (139.1 mg in the placebo group and $57.0 \mathrm{mg}$ in the piribedil group [p $<0.0001]$ in the FAS and $130.7 \mathrm{mg}$ in the placebo group and $52.2 \mathrm{mg}$ in the piribedil group [p $=0.0004]$ in the PPS). 


\begin{tabular}{|c|c|c|c|c|c|c|c|c|c|}
\hline \multicolumn{2}{|c|}{$\begin{array}{l}\text { Name of Company: } \\
\text { I.R.I.S. } \\
6 \text { place des Pléiades } \\
92415 \text { Courbevoie - FRANCE }\end{array}$} & \multicolumn{4}{|c|}{$\begin{array}{l}\text { Individual Study Table } \\
\text { Referring to Part } \\
\text { of the Dossier }\end{array}$} & \multicolumn{4}{|c|}{$\begin{array}{l}\text { (For National Authority Use } \\
\text { only) }\end{array}$} \\
\hline \multicolumn{2}{|c|}{$\begin{array}{l}\text { Name of Finished Product: } \\
\text { Trivastal }{ }^{\circledR} 50 \mathrm{mg} \mathrm{LP}\end{array}$} & \multicolumn{4}{|c|}{ Volume: } & & & & \\
\hline \multicolumn{2}{|c|}{$\begin{array}{l}\text { Name of Active Ingredient: } \\
\text { Piribedil (S4200) }\end{array}$} & \multicolumn{4}{|c|}{ Page: } & & & & \\
\hline \multicolumn{10}{|c|}{ Efficacy Results (Cont'd): } \\
\hline \multicolumn{10}{|c|}{$\begin{array}{l}\text { During the first } 7 \text { months of treatment, a decrease in Hoehn and Yahr stage was seen with piribedil treatment, } \\
\text { which was significantly different to placebo }(\mathrm{p}<0.008, \text { FAS). }\end{array}$} \\
\hline \multicolumn{10}{|c|}{$\begin{array}{l}\text { While the MADRS score remained relatively stable in both groups over } 7 \text { months, a decrease of } 1 \text { point on the } \\
\text { Beck depression inventory was demonstrated in the piribedil group and an increase of } 1.2 \text { points in the } \\
\text { placebo group. }\end{array}$} \\
\hline \multicolumn{10}{|c|}{$\begin{array}{l}\text { In general, the effects of piribedil on cognitive function from baseline to the last post-baseline visit did not } \\
\text { appear to differ from placebo. } \\
\text { In piribedil-treated patients, the PDQL total score increased } 5.0 \text { points from baseline to last post-baseline visit, } \\
\text { compared with a decrease from baseline to last post-baseline visit of } 6.1 \text { points in placebo-treated patients. }\end{array}$} \\
\hline \multicolumn{10}{|c|}{$\begin{array}{l}\text { Emergent adverse events: } \\
\text { Overall, } 63.0 \% \text { of patient } \\
\text { piribedil treatment group). }\end{array}$} \\
\hline \multirow[t]{2}{*}{ Preferred term } & \multicolumn{3}{|c|}{$\begin{array}{l}\text { Placebo } \\
(\mathrm{N}=\mathbf{2 0 5})\end{array}$} & \multicolumn{3}{|c|}{$\begin{array}{l}\text { Piribedil } \\
(\mathrm{N}=\mathbf{2 0 0})\end{array}$} & \multicolumn{3}{|c|}{$\begin{array}{c}\text { All } \\
(\mathrm{N}=\mathbf{4 0 5})\end{array}$} \\
\hline & NEAE & $\mathbf{n}$ & $\%$ & NEAE & $\mathbf{n}$ & $\%$ & NEAE & $\mathbf{n}$ & $\%$ \\
\hline Nausea & 8 & 8 & 3.9 & 24 & 24 & 12.0 & 32 & 32 & 7.9 \\
\hline Hypertension & 10 & 9 & 4.4 & 20 & 19 & 9.5 & 30 & 28 & 6.9 \\
\hline Dizziness & 10 & 9 & 4.4 & 17 & 15 & 7.5 & 27 & 24 & 5.9 \\
\hline Anxiety & 9 & 9 & 4.4 & 13 & 13 & 6.5 & 22 & 22 & 5.4 \\
\hline Hypotension postural & 8 & 8 & 3.9 & 13 & 13 & 6.5 & 21 & 21 & 5.2 \\
\hline Insomnia & 6 & 6 & 2.9 & 15 & 13 & 6.5 & 21 & 19 & 4.7 \\
\hline Constipation & 6 & 6 & 2.9 & 13 & 13 & 6.5 & 19 & 19 & 4.7 \\
\hline Depression & 12 & 12 & 5.9 & 7 & 7 & 3.5 & 19 & 19 & 4.7 \\
\hline Somnolence & 6 & 6 & 2.9 & 12 & 12 & 6.0 & 18 & 18 & 4.4 \\
\hline Back pain & 8 & 8 & 3.9 & 11 & 9 & 4.5 & 19 & 17 & 4.2 \\
\hline Oedema peripheral & 7 & 7 & 3.4 & 11 & 10 & 5.0 & 18 & 17 & 4.2 \\
\hline Dyspepsia & 8 & 7 & 3.4 & 10 & 9 & 4.5 & 18 & 16 & 4.0 \\
\hline Abdominal pain & 4 & 4 & 2.0 & 12 & 12 & 6.0 & 16 & 16 & 4.0 \\
\hline \multicolumn{10}{|c|}{$\begin{array}{l}\text { Only data experienced by } \geq 4 \% \text { of patients are presented } \\
\text { NEAE: Number of emergent adverse events; } N \text { : total number of exposed patients in the considered treatment group } \\
n: \text { Number of patients affected; } \%=n / N^{*} 100\end{array}$} \\
\hline \multicolumn{10}{|c|}{$\begin{array}{l}\text { While no action was taken for } 44.0 \% \text { of these patients }(38.0 \% \text { in placebo and } 50.0 \% \text { in piribedil groups }) \text {, } \\
\text { medication was stopped in } 19(4.7 \%) \text { of these patients }(2.0 \% \text { in placebo and } 7.5 \% \text { in piribedil groups }) \text {. }\end{array}$} \\
\hline \multicolumn{10}{|c|}{$\begin{array}{l}\text { Treatment-related emergent adverse events: } \\
\text { Overall, } 34.1 \% \text { of patients in the SS experienced at least } 1 \text { treatment-related EAE }(25.4 \% \text { in the placebo and } \\
43.0 \% \text { in the piribedil treatment group). }\end{array}$} \\
\hline \multicolumn{10}{|c|}{$\begin{array}{l}\text { Severe emergent adverse events } \\
\text { Overall, } 10.4 \% \text { of patients in the SS experienced at least } 1 \text { severe EAE ( } 6.3 \% \text { in the placebo and } 14.5 \% \text { in the } \\
\text { piribedil treatment group). }\end{array}$} \\
\hline
\end{tabular}




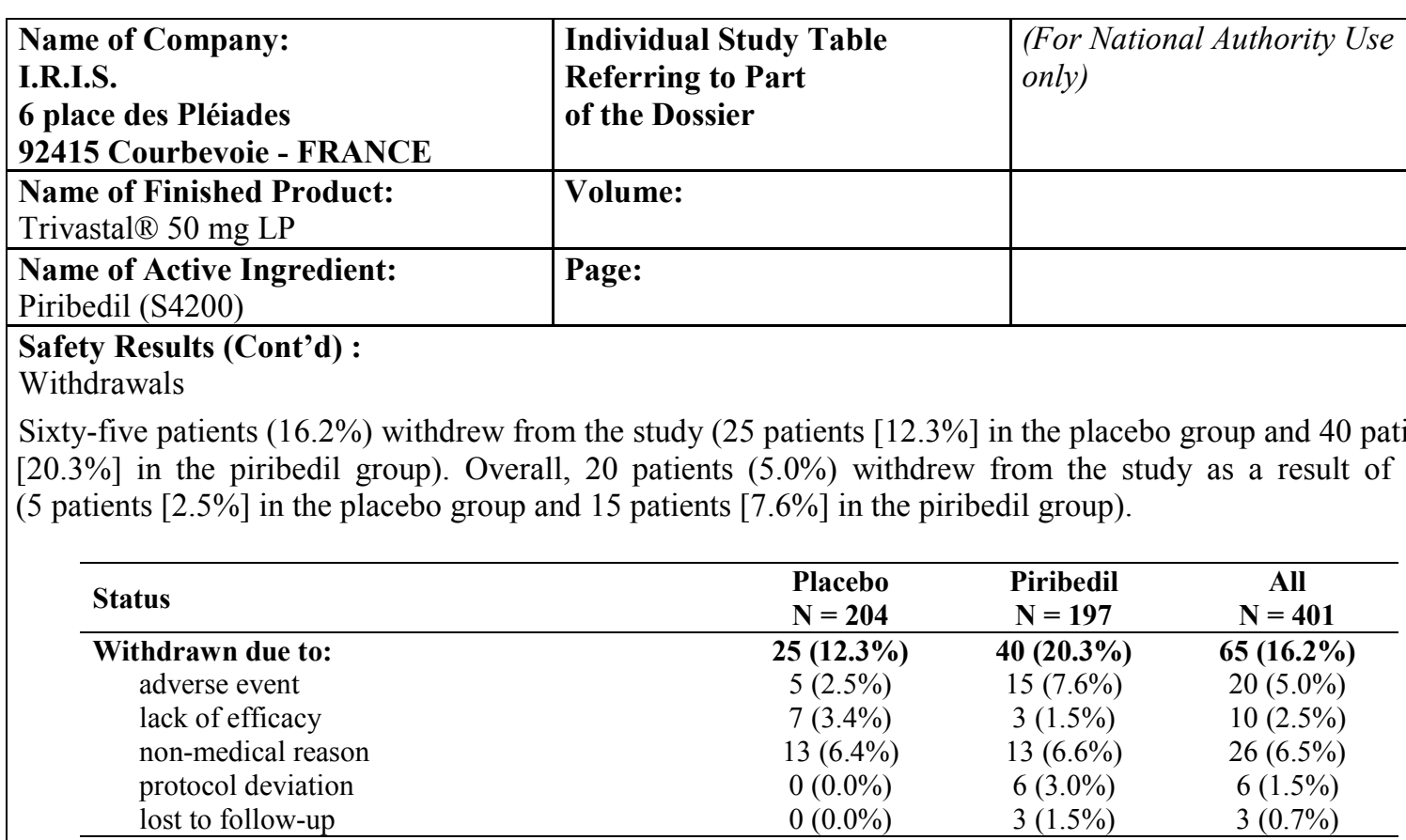

Overall, treatment was stopped in 19 patients (4.7\%) due to an EAE, as follows:

\begin{tabular}{|c|c|c|c|c|c|c|c|c|c|}
\hline \multirow[t]{2}{*}{ System organ class } & \multicolumn{3}{|c|}{$\begin{array}{l}\text { Placebo } \\
(\mathrm{N}=\mathbf{2 0 5})\end{array}$} & \multicolumn{3}{|c|}{$\begin{array}{l}\text { Piribedil } \\
(\mathrm{N}=\mathbf{2 0 0})\end{array}$} & \multicolumn{3}{|c|}{$\begin{array}{c}\text { All } \\
(\mathrm{N}=\mathbf{4 0 5})\end{array}$} \\
\hline & NEAE & $\mathbf{n}$ & $\%$ & NEAE & $\mathbf{n}$ & $\%$ & NEAE & $\mathbf{n}$ & $\%$ \\
\hline All events & 6 & 4 & 2.0 & 17 & 15 & 7.5 & 23 & 19 & 4.7 \\
\hline Gastrointestinal system disorders & $\mathbf{0}$ & $\mathbf{0}$ & $\mathbf{0 . 0}$ & 6 & 5 & 2.5 & 6 & 5 & 1.2 \\
\hline Abdominal pain & 0 & 0 & 0.0 & 1 & 1 & 0.5 & 1 & 1 & 0.2 \\
\hline Dyspepsia & 0 & 0 & 0.0 & 1 & 1 & 0.5 & 1 & 1 & 0.2 \\
\hline Nausea & 0 & 0 & 0.0 & 1 & 1 & 0.5 & 1 & 1 & 0.2 \\
\hline Pancreatitis & 0 & 0 & 0.0 & 1 & 1 & 0.5 & 1 & 1 & 0.2 \\
\hline Vomiting & 0 & 0 & 0.0 & 2 & 2 & 1.0 & 2 & 2 & 0.5 \\
\hline Psychiatric disorders & $\mathbf{0}$ & $\mathbf{0}$ & $\mathbf{0 . 0}$ & 5 & 5 & 2.5 & 5 & 5 & 1.2 \\
\hline Hallucination & 0 & 0 & 0.0 & 4 & 4 & 2.0 & 4 & 4 & 1.0 \\
\hline Psychosis & 0 & 0 & 0.0 & 1 & 1 & 0.5 & 1 & 1 & 0.2 \\
\hline Cardiovascular disorders, general & $\mathbf{0}$ & $\mathbf{0}$ & $\mathbf{0 . 0}$ & 2 & 2 & 1.0 & 2 & 2 & 0.5 \\
\hline Cardiac failure left & 0 & 0 & 0.0 & 1 & 1 & 0.5 & 1 & 1 & 0.2 \\
\hline Hypotension postural & 0 & 0 & 0.0 & 1 & 1 & 0.5 & 1 & 1 & 0.2 \\
\hline $\begin{array}{l}\text { Central and peripheral nervous } \\
\text { system disorders }\end{array}$ & 4 & 2 & 1.0 & $\mathbf{0}$ & $\mathbf{0}$ & 0.0 & 4 & 2 & 0.5 \\
\hline Hypokinesia & 1 & 1 & 0.5 & 0 & 0 & 0.0 & 1 & 1 & 0.2 \\
\hline Parkinsonism aggravated & 2 & 2 & 1.0 & 0 & 0 & 0.0 & 2 & 2 & 0.5 \\
\hline Tremor & 1 & 1 & 0.5 & 0 & 0 & 0.0 & 1 & 1 & 0.2 \\
\hline Liver and biliary system disorders & 1 & 1 & 0.5 & 1 & 1 & 0.5 & 2 & 2 & 0.5 \\
\hline Hepatitis cholestatic & 1 & 1 & 0.5 & 0 & 0 & 0.0 & 1 & 1 & 0.2 \\
\hline Jaundice & 0 & 0 & 0.0 & 1 & 1 & 0.5 & 1 & 1 & 0.2 \\
\hline $\begin{array}{l}\text { Myo endo pericardial and valve } \\
\text { disorders }\end{array}$ & $\mathbf{0}$ & $\mathbf{0}$ & $\mathbf{0 . 0}$ & 2 & 2 & 1.0 & 2 & 2 & 0.5 \\
\hline Myocardial infarction & 0 & 0 & 0.0 & 1 & 1 & 0.5 & 1 & 1 & 0.2 \\
\hline Myocardial ischaemia & 0 & 0 & 0.0 & 1 & 1 & 0.5 & 1 & 1 & 0.2 \\
\hline Body as a whole - general disorders & $\mathbf{0}$ & $\mathbf{0}$ & $\mathbf{0 . 0}$ & 1 & 1 & 0.5 & 1 & 1 & 0.2 \\
\hline Asthenia & 0 & 0 & 0.0 & 1 & 1 & 0.5 & 1 & 1 & 0.2 \\
\hline Resistance mechanism disorders & 1 & 1 & \begin{tabular}{c|}
0.5 \\
\end{tabular} & 0 & $\mathbf{0}$ & $\begin{array}{l}0.0 \\
\end{array}$ & 1 & 1 & 0.2 \\
\hline Sepsis & 1 & 1 & 0.5 & 0 & 0 & 0.0 & 1 & 1 & 0.2 \\
\hline $\begin{array}{l}\text { NEAE: number of emergent adverse events } \\
N: \text { total number of exposed patients in the co } \\
n: \text { number of patients affected } \\
\%=n / N^{*} 100\end{array}$ & ed tre & & & & & & & & \\
\hline
\end{tabular}




\begin{tabular}{|c|c|c|}
\hline $\begin{array}{l}\text { Name of Company: } \\
\text { I.R.I.S. } \\
6 \text { place des Pléiades } \\
92415 \text { Courbevoie - FRANCE }\end{array}$ & $\begin{array}{l}\text { Individual Study Table } \\
\text { Referring to Part } \\
\text { of the Dossier }\end{array}$ & $\begin{array}{l}\text { (For National Authority Use } \\
\text { only) }\end{array}$ \\
\hline $\begin{array}{l}\text { Name of Finished Product: } \\
\text { Trivastal } \AA 50 \mathrm{mg} \text { LP }\end{array}$ & Volume: & \\
\hline $\begin{array}{l}\text { Name of Active Ingredient: } \\
\text { Piribedil (S4200) }\end{array}$ & Page: & \\
\hline \multicolumn{3}{|l|}{ Conclusion: } \\
\hline \multicolumn{3}{|c|}{$\begin{array}{l}\text { Over a } 7 \text {-month period, piribedil ( } 150 \text { to } 300 \mathrm{mg} / \text { day) proved to be effective in reducing motor symptoms in } \\
\text { de novo parkinsonian patients (mean UPDRS III total score changes from baseline to last post-baseline visit in } \\
\text { monotherapy of piribedil versus placebo in the FAS; least squares [LS] mean difference [and } 95 \% \mathrm{CI} \text { of } 7.26 \\
\text { [5.38, } 9.14] ; \mathrm{p}<0.0001) \text {. There was a } 42.2 \% \text { response rate with piribedil versus } 13.6 \% \text { with placebo (Odds } \\
\text { ratio }=4.69, \mathrm{p}<0.0001 \text { ). This beneficial effect was also demonstrated by changes in UPDRS II (ADL) for } \\
\text { piribedil versus placebo (LS mean difference [and } 95 \% \mathrm{CI} \text { ] of } 2.71[1.80,3.62] ; \mathrm{p}<0.0001 \text { ). }\end{array}$} \\
\hline \multicolumn{3}{|c|}{$\begin{array}{l}\text { Although the number of patients remaining in the study at } 7 \text { months was similar in both groups, the number of } \\
\text { patients receiving L-dopa rescue treatment was lower for the piribedil-treated group (relative risk }=3.02 \text {, } \\
\text { p }<0.0001 \text { ). }\end{array}$} \\
\hline \multicolumn{3}{|c|}{$\begin{array}{l}\text { Piribedil was associated with a safety profile consistent with other dopamine agonists including nausea, } \\
\text { insomnia, hypertension, dizziness, orthostatic hypotension, hallucinations and somnolence. The number of } \\
\text { reported AEs was higher in piribedil-treated patients, especially gastrointestinal disorders. The percentage of } \\
\text { emergent psychiatric events was comparable between piribedil-treated patients }(23.0 \%) \text { and placebo-treated } \\
\text { patients }(17.6 \%) \text {. }\end{array}$} \\
\hline \multicolumn{3}{|c|}{$\begin{array}{l}\text { There were no notable mean changes from baseline to Month } 7 \text { in any biochemistry or haematology } \\
\text { parameters. Potentially clinically significant changes were not experienced by more than } 10 \text { patients for any } \\
\text { given biochemistry or haematology parameter. } \\
\text { Results of this large randomised, double blind, placebo controlled study confirm good efficacy of piribedil on } \\
\text { all motor symptoms in de novo patients with Parkinson's disease, in true monotherapy conditions. These } \\
\text { results support the use of the dopamine agonist piribedil as an effective initial therapeutic option, also able to } \\
\text { significantly delay the need for an L-dopa adjunct. }\end{array}$} \\
\hline \multicolumn{3}{|l|}{ Date of report: 10 August 2005} \\
\hline
\end{tabular}

